\title{
Sequential Pathways of Anther Dehiscence in Sesbania speciosa
}

\author{
Neeru Seth and M.R. Vijayaraghavan \\ Department of Botany, University of Delhi, Delhi 110007, India
}

Accepted July 4, 1991

Maturation and desiccation of anther tissue are essential for anther dehiscence. The ripe anthers dehisce over a considerable range of temperature and humidity. The anther dehiscence involves two distinct processes: (a) Endothecium differentiates and develops the fibrous thickenings and surrounds the anther locule, except at the presumptive anther dehiscence site, namely the stomium (b) Endothecium becomes active and develops forces that help in the rupture of anther wall along the stomium region. Strasburger (1902) reported at the growing pollen disrupted the septum and that lytic enzymes opened the stomium. Later, it was observed that lytic enzymes were involved both in the rupture of the septum and the stomium (Namikawa 1919, Becquerel 1932). However, Woycicki (1924a, b) suggested only the mechanical disruption of stomium. Venkatesh (1957) studied the anther dehiscence in many species of Cassia and reported that dehiscence occurs only at the sterile anther tip, where the short linear stomia develop. Keijzer (1987a, b, c) studied the anther dehiscence in Gasteria verrucosa and Lilium hybrida and reiterated the enzymatic opening of the septum between two locules, followed by mechanical rupture of the tapetum followed by opening of the stomium by centripetal forces of the highly turgescent eptidermis and endothecium; outward bending of the locule walls by the centrifugal forces of the dehydrating epidermis and endothecium; roles of sporopollenin and anther filament. Only, the role of anther filament has received detailed attention (Schmid 1976, Schmid and Alpert 1977). A comprehensive description of the process of anther dehiscence has never been attempted in the members of Papilionoideae. Such studies can furnish information about the changes that occur at the cellular level which preforces cells of identical origin to differentiate and perform distinct specialized functions. This could provide an insight into the relationship between the structure and formation of anther wall layers, septum and stomium.

\section{Material and methods}

Anthers of Sesbania speciosa Taubert Ex Engler at various stages of development, were collected from the plants grown in the botanical garden, Department of Botany, University of Delhi, Delhi. For light microscopy the anthers were fixed in precooled $10 \%$ aqueous acrolein. Dehydration, infiltration and embedding in glycol methacrylate was done (Vijayaraghavan and Shukla 1990). Two micron sections were cut on a rotary microtome using glass knives fitted to an indigenously devised glass knives adaptor. Insoluble polysaccharides were localized with PAS reaction (modified after Feder and O'Brien 1968); sporopollenin (Vijayaraghavan and Shukla 1990).

For scanning electron microscopy, anthers at different stages of dehiscence were fixed in $3 \%$ glutaraldehyde in $0.2 \mathrm{M}$ phosphate buffer $\left(\mathrm{pH} \mathrm{7.2)}\right.$ at $4^{\circ} \mathrm{C}$ for $4 \mathrm{hr}$. Washed the material with 2 changes of cold phosphate buffer $(0.2 \mathrm{M}, \mathrm{pH} 7.2)$. Dehydration was done in cold aqueous ascending series from 10 , through $90 \%$ acetone followed by two changes in absolute acetone for $15 \mathrm{~min}$. The material was later passed through dry acetone. The dehydrated material was subjected to critical point drying and later mounted on aluminium studs with the help of 


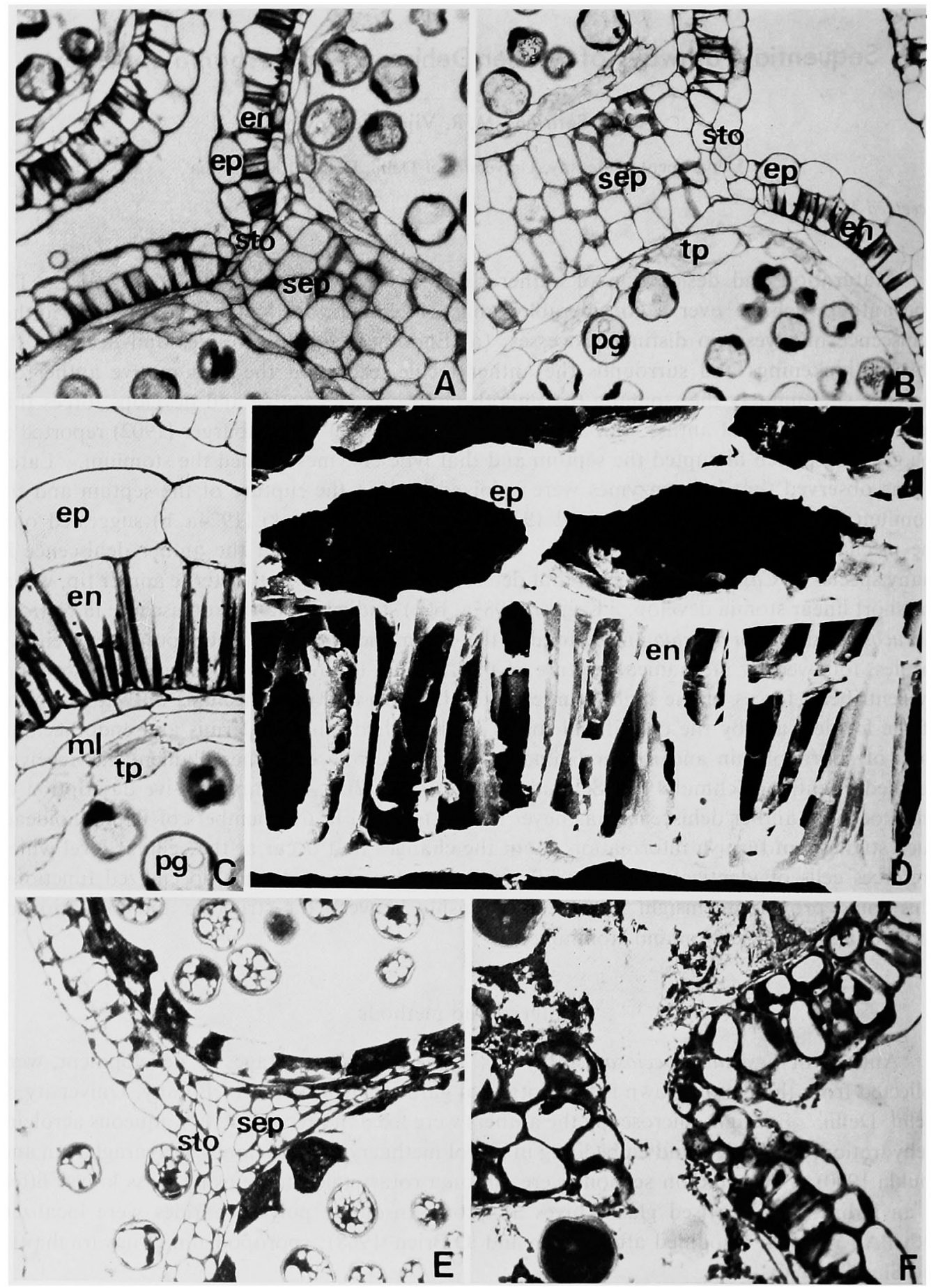

Fig. 1. A-F Sesbania speciosa (en, endothecium, $e p$, epidermis; $m l$, middle layer; sep, septum, sto, stomium; $t p$, tapetum). A, B Portions of transverse section of anther at uninucleate microspore stage, stained for insoluble polysaccharide showing adjacent locules and intervening septum. The meeting point of adjacent epidermis has small round epidermal cells and the endothecial cells are absent at this point. The epidermal cells are devoid of polysaccharide grains and endothecial cells show negligible amount of polysaccharide grains. The initiation of endothecial wall thickenings is noticeable. $\times 900$. C A portion of anther wall stained for insoluble polysaccharides to show 
double sided adhesive tape and silver paint. The material was coated with thin layer of standard silver in a vacuum coating unit fitted with a revolving stage. Observations were made with Philips SEM 501 B Model.

\section{Observations}

The first observable cytological change relating to anther opening occurs when the microspores are just released from the tetrads. At this stage, cells of the epidermis and the endothecium lose a few polysaccharide grains and expand both in tangential and radial directions (Fig. 1A, B). During the non-vacuolate to early maturation stages in pollen grain development U-shaped and branched endothecial cell wall thickenings are deposited (Fig. 1C, D). A small zone between two adjacent locules, and a few endothecial cells always remain small and are bereft of U-shaped wall thickenings and thus simulate other septal parenchymatous cells. At the early maturation period of the pollen grains, the cells of septum show lax arrangement and lack polysaccharide grains. The only tissue that develops uniformly around the locule is the tapetum. A few epidermal cells, facing the septum, do not expand unlike their sib. This zone/region is known as the stomium. Later, the cells of the septum dissociate from each other and from the neighbouring tissues (Fig. 1E, F). This process starts with the formation of gaps in the middle lamella and later extends around the cells. The tapetal cells, however, remain united and this keep the locules sealed and hold the dissociated septal cells in their original position. At this stage, the inner tangential tapetal cells are lined only by sporopollenin containing übish bodies.

The generative cell is delimited from the intine and at this stage the volume of the pollen mass exceeds the capacity of the locules. The slit in the septum widens. The tapetum breaks and the pollen grains of the two adjactent locules become confluent and the anther is sealed by two small epidermal cells of the stomium. The mature anther walls show deposition of cutin on the surface (Fig. 2D). At anthesis, the cells of the epidermis and the endothecium become differentially dehydrated and shrink. This differential shrinkage of these walls develop inside the anther/s mechanical pressure that leads to the outward bending of the locule walls (Figs. 2A-C).

\section{Discussion}

The anthers of Sesbania speciosa are dehisced by longitudinal slits. The cells of septum dissociate from each other and from neighbouring tissues. Keijzer (1987a) in Gasteria verrucosa reported enzymatic breakdown of cell wall materials which leads to the opening of the septum. In Sesbania speciosa, the completely separated septum cells, together with an intact tapetum supports in addition a mechanical device. Woycicki (1924a), showed that the collenchyma-like cell walls mainly consist of pectin, indicating a possible role of pectinase in opening the septum. Mechanical rupture of septum is also supported by the observation that when the endothecium cells desiccate the pressure created inside these cells leads to their lyses.

densely stained, $U$ shaped and branched thickneing in endothecial cells. $\times 1400$. D A scanning electron micrograph of anther wall to show epidermis and endothecium. The endothecial thickenings are $U$ shaped and show branching which are interconnected $\times 2250$. E, F Portions of transverse section of anther at early maturation stages stained for total proteins. At the apex of the septum the cells show lax arrangement (E) which later dissociate from each other. The tapetal cells bordering the anther locule subsequently become disrupted to form a continuum between the two adjacent locules $(F)$. The pollen grains of each adjacent locule come into contact with each other. The anther is bordered by the epidermal cells of stomium that later give way, curve outward due to the pressure exerted by the pollen grains. $\times 1400$. 

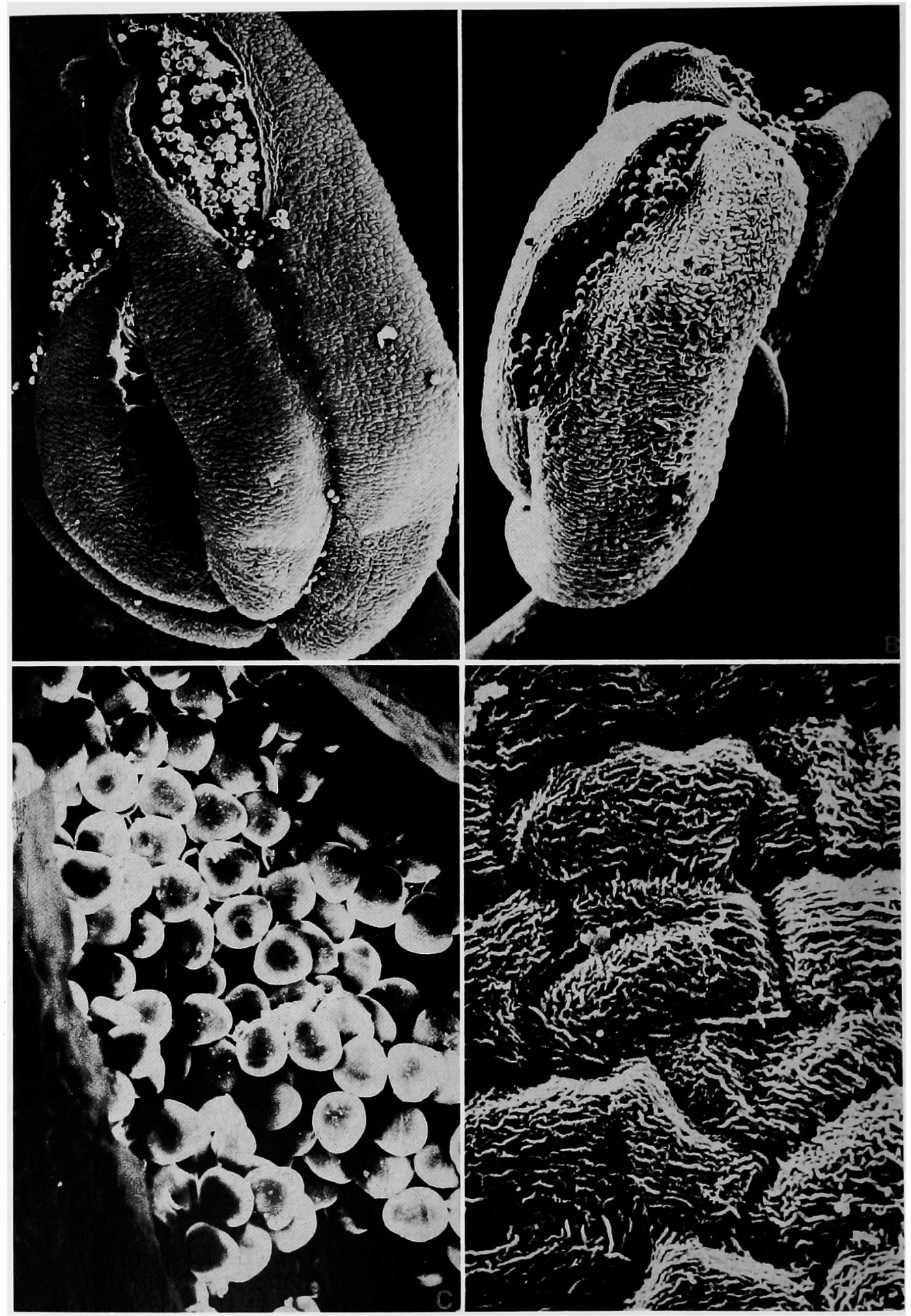

Fig. 2. A-D. A, B Scanning electron micrographs of anther to show anther dehiscence through longitudinal slit. The wall layers bend outwards to widen the gap. $\times 100$. C Portion from B enlarged to show release of pollen grains. $\times 570$. D Scanning electron micrograph of anther to show cutin deposition on epidermal cells. $\times \mathbf{5 7 0}$. 
Septal opening is well-known in male-sterile anthers (Keijzer 1987a).

In Sesbania speciosa during early maturation stage of pollen grains, the inner tangential wall of tapetum obliterates and are lined with fine hayline granules. On the border between the tapetum and pollen grains, the pectins and cellulose are gradually replaced by sporopollenin. There is, thus, a shift from hydrophilic condition to hydrophobic properties (HeslopHarrison 1968). These orbicules might form a non-wettable surface on the locular side that effects an easy dispersal of pollen (Heslop-Harrison and Dickinson 1969). In Sesbania speciosa it is the pressure exerted by pollen mass as well the sporopollenin orbicules in the tapetal membrane lead to rupture of tapetum. The only structures that are capable of exerting resistance at this stage, are the tapetal membrane. In Lilium hybrida, the outward bending of the locule walls and in Gasteria verrucosa the pressure of the pollen mass break the tapetal membranes (Keijzer 1987a). No special mechanisms appear to operate during breakage but are ruptured any slight force once the septum has opened.

In Sesbania speciosa, as the septum and tapetum are disrupted, the pollen mass comes indirect contact with the stomium. The pressure exerted by the pollen mass as well by the adjacent endothecial cells lead to opening of stomium. It is concluded that the outward bending of the endothecium is responsible for opening both the septum and the stomium.

In Sesbania speciosa, the spetum cells lose most of the starch. The epidermis and the endothecium lose water and shrink. The thick walls of the endothecium do so to a lesser extent. It is the differential shrinkage of these cells that leads to outward opening of the outer wall. Cuticle present on the mature anther surface accelerate evaporation (Keijzer 1985, 1987a). In Lilium hybrida which has persistent middle layers, the cell walls shrink on both sides of the inner tangential wall of the endothecium wall. Towards the inside the walls of the middle layers are present. The force generated on the outside appears to be strong for two reasons (a) the distance between the shrinking cell walls in the outside and the inner tangential endothecium wall is fixed. (b) The epidermal and endothecium cell walls are generally thick and this is important for hygroscopic mechanisms. However the epidermal size reduction in some taxa of this tissue (Bonnier and Du Sablon 1903, Schneider 1908) indicate that only the endothecium is involved in the final bending of the anther locule wall. Thus in Sesbania speciosa the anther dehiscence proceeds through the following sequence of events.

i) The epidermis and endothecium cells expand. The branched wall thickening occur only in the endothecium leaving a parenchymatous septum between two juxtaposed anther locule.

ii) The cells of the septum later mechanically and enzymatically dissociate.

iii) The tapeta of two adjacent locules disrupt as a result of pressure exerted by the pollen mass and due to the shift from the hydrophilic to the hydophobic properties of the tapetal membrane due to synthesis of sporopollenin.

iv) Stomium ruptures mechanically due to the pressure exerted by the desiccating endothecium.

\section{Summary}

The mechanism of anther dehiscence in Sesbania speciosa was followed using light and scanning electron microscopic techniques. The following sequence of events occur (i) Epidermis and endothecium expand, (ii) Branched wall thickenings occur only in the endothecium cells, (iii) Septum cells dissociate, (iv) Tapeta of two adjacent locules lyse due to pressure exerted by pollen grains.(v) Stomium ruptures due to the pressure exerted by the desiccating endothecium. 


\section{Acknowledgements}

Dr Neeru Seth is grateful to the Council of Scientific and Industrial Research, New Delhi for the award of Research Associateship.

\section{References}

Becquerel, P. 1932. La déhiscence de l'anthére du Lis blanc. Comptes Rendus Hebdomadaires des Séaznces de l'Aca. de Sci., Paris, Ser. D. 195: 165-167.

Bonnier, G. and Du Sablon, L. 1903. Cours de Botanique. Libr. Géné. de l'Enseignement, Paris.

Feder, N. and O'Brien, T. P. 1968. Plant microtechnique: Some principles and new methods. Amer. J. Bot. 55: $123-142$.

Heslop-Harrison. J. 1968. Pollen wall development. Science 161 : 230-237.

- and Dickinson, H. G. 1969. Time relationships of sporopollenin synthesis associated with tapetum and microspores in Lilium. Planta 84: 199-214.

Keijzer, C. J. 1985. The functions of the endothecium. Acta Bot. Neerlandica 34: 130-131.

-1987a. The processes of anther dehiscence and pollen dispersal. I. The opening mechanism of longitudinally dehiscing anthers. New Phytologist 105: 487-498.

- 1987b. The processes of anther dehiscence and pollen dispersal. II. The formation and the transfer mechanism of pollen kitt, cell wall development in the locule tissues and a function of the orbicules in pollen dispersal. Ditto 105: 499-507.

- Hoek, I. H.S. and Willemse, M. T. M. 1987c. The processes of anther dehiscence and pollen dispersal. III. The dehydration of the filament tip and the anther in three monocotyledonous species. Ditto 106: 281-287.

Namikawa, I. 1919. Über das öffnen der Antheren bei einigen Solanaceen. Bot. Mag. (Tokyo) 33: 62-69.

Schmid, R. 1976. Filament histology and anther dehiscence. Bot. J. Lin. Soc. 73: 303-315.

- and Alpert, P. H. 1977. A test of Burck's hypothesis relating anther dehiscence to nectar secretion. New Phytologist. 78: 487-498.

Schneider, J. M. 1908. Der öffnungsmechanisms der Tulipa Anthere. Ber. der Deu. Bot. Gesell. 29: 406-416.

Strasburger, E. 1902. Ein Beitrag zur Kennthiss von Ceratophyllum submersum. Fahrbücher für wissenschaftliche. Botanik 37: 477-524.

Venkatesh, C.S. 1957. The form, structure and special ways of dehiscence of anthers of Cassia. 3. Subgenus Senna. Phytomorphology 7: 253-273.

Vijayaraghavan, M. R. and Shukla, A. K. 1990. Histochemistry-Theory and Practice. Bishen Singh Mahendra Pal Singh. Dehra Dun, India.

Woycicki, Z. 1924a. Recherches sur la déhiscence des anthéres et le rôle du stomium. Rev. Géné. de Bot. 36: 196-212.

- 1924b. Recherches sur la déhiscence des anthéres et le röle du stomium. 2. La formation de la fente dans les anthéres et las phenoménes qui laccompagnent. Rev. Géné. de Bot. 36: 253-268. 